\title{
Hydrochemical Synthesis of $\mathrm{HgS}_{1-x} \mathrm{Se}_{x}$ Film Solid Solutions
}

\author{
M.A. Sozanskyi*, P.Yo. Shapoval, V.E. Stadnik, O.P. Kyrulo, M.M. Laruk \\ Lviv Polytechnic National University, 12, S. Bandera St., 79013 Lviv, Ukraine
}

(Received 06 July 2021; revised manuscript received 20 October 2021; published online 25 October 2021)

\begin{abstract}
Solid solution films of mercury sulfide-selenide $\left(\mathrm{HgS}_{1-x} \mathrm{Se}_{x}\right)$ were synthesized on glass substrates by the hydrochemical deposition method. Aqueous solutions of mercury (II) nitrate, thiourea, sodium selenosulfate and trisodium citrate were used. Theoretical calculations of the boundary conditions for the formation of mercury sulfide, mercury selenide and mercury oxide were made in the mercury-thiourea-citrate system. According to the performed X-ray and elemental analysis, the obtained film samples are single phase and consist of $\mathrm{HgS}_{1-x} \mathrm{Se}_{x}$ substitutional solid solutions. The effect of sodium selenosulfate concentration on the $\mathrm{S}$-Se degree of substitution of $\mathrm{HgS}_{1-x} \mathrm{Se}_{x}$ coatings was investigated. It was established that the $x$ parameter changes from 0.068 to 0.334 with increasing $\mathrm{Na}_{2} \mathrm{SeSO}_{3}$ content from $1 \cdot 10^{-5}$ to $1 \cdot 10^{-4} \mathrm{M}$. At the same time, the $\mathrm{HgS}_{1-x} \mathrm{Se}_{x}$ structure modification changes from cinnabar to sphalerite. Higher concentrations of sodium selenosulfate give too high formation rate of the final product and, accordingly, it is difficult to obtain coatings. The morphological and optical properties of $\mathrm{HgS}_{1-x} \mathrm{Se}_{x}$ films were examined. Their surface is solid, smooth and has a small amount of surface defects. The optical transmission of $\mathrm{HgS}_{1-x} \mathrm{Se}_{x}$ films increases in the investigated wavelength range from 340 to $900 \mathrm{~nm}$. The transmission curve has a jump in the $400 \mathrm{~nm}$ region, which shifts to the longer wavelength region with increasing selenium content in $\mathrm{HgS}_{1-x} \mathrm{Se}_{x}$, accordingly, the optical band gap of the films decreases from 2.7 to $2.43 \mathrm{eV}$.
\end{abstract}

Keywords: Mercury sulfide, Mercury selenide, Films, Solid Solution, Chemical deposition, Optical properties.

\section{INTRODUCTION}

In recent years, ways to modify conventional semiconductor materials have been actively studied. These include galvanic replacement [1-3], doping with various impurities [4-6], substitution of elements in the form of solid solutions [7-8], etc. The listed methods allow to adjust the properties of semiconductors for their more efficient use in electronic applications and devices. The present work is devoted to substitutional solid solutions. Their properties can be regulated by the composition, which is set by the parameters of the material synthesis.

Substitutional solid solution films of mercury sulfide-selenide $\left(\mathrm{HgS}_{1-x} \mathrm{Se}_{x}\right)$ belong to $\mathrm{A}^{\mathrm{II}} \mathrm{B}^{\mathrm{VI}}$ semiconductor materials. They are intermediates between mercury sulfide (HgS) and mercury selenide ( $\mathrm{HgSe})$. As well as mercury chalcogenide films, $\mathrm{HgSS}_{1-x} \mathrm{Se}_{x}$ coatings have been little studied. This is because they are difficult to obtain by a simple chemical deposition method from water solution, similarly to $\mathrm{HgS}$ and $\mathrm{HgSe}$ films, which is shown by a small number of relevant publications given in the reviews $[9,10]$. The reason is the very low solubility of mercury sulfide and mercury selenide, and, accordingly, the high rate of their formation in the form of precipitates. The way to solve this problem is to use strong complex-forming agents for mercury and the selection of such synthesis parameters (reagents concentration, temperature, duration of process, $\mathrm{pH}$ value, etc.) at which the quality of the obtained films is better.

Obtaining $\mathrm{HgS}_{1-x} \mathrm{Se}_{x}$ films with different degrees of substitution of S-Se chalcogenides will allow to obtain a material with the necessary and predetermined semiconductor characteristics.

\section{EXPERIMENTAL DETAILS}

\subsection{Materials}

The synthesis of $\mathrm{HgS}_{1-x} \mathrm{Se}_{x}$ films was carried out from a working solution based on chemical deposition of HgS films at optimized conditions described (in detail) in [11]. The composition of working solutions was as follows: $0.01 \mathrm{M}$ mercury (II) nitrate $\left(\mathrm{Hg}\left(\mathrm{NO}_{3}\right)_{2}\right)$; $0.02 \mathrm{M}$ thiourea $\left(\left(\mathrm{NH}_{2}\right)_{2} \mathrm{CS}\right)$, as a complexing agent for $\mathrm{Hg}^{2+}$ and a sulfurizing agent at the same time; from $1 \cdot 10^{-5}$ to $1 \cdot 10^{-4} \mathrm{M}$ of sodium selenosulfate $\left(\mathrm{Na}_{2} \mathrm{SeSO}_{3}\right)$ as a selenizing agent, and $0.015 \mathrm{M}$ trisodium citrate $\left(\mathrm{Na}_{3} \mathrm{C}_{6} \mathrm{H}_{5} \mathrm{O}_{7}\right)$ as a $\mathrm{pH}$ regulator (it can also show complexation properties). The total volume of the solution was $20 \mathrm{ml}$, the synthesis duration was $5 \mathrm{~min}$, the temperature was $90^{\circ} \mathrm{C}$.

Deposition of $\mathrm{HgS}_{1-x} \mathrm{Se}_{x}$ films was performed on pre-cleaned glass substrates $\left(18 \times 18 \mathrm{~mm}^{2}\right)$. The deposition was carried out in a glass bath, after which the substrates were removed, washed with distilled water, and dried in air. The synthesized samples of $\mathrm{HgS}_{1-x} \mathrm{Se}_{x}$ films were dark brown in color. Their adhesion to the glass substrate was weak. The films could be removed by applying small mechanical efforts.

\subsection{Analysis}

$\mathrm{X}$-ray diffraction (XRD) analysis of the synthesized film samples was made using a DRON-3.0 X-ray diffractometer ( $\mathrm{CuKa}$ radiation). The preliminary processing of the experimental diffraction arrays in order to identify the phases were carried out using PowderCell program [12]

The optical transmission spectra of the films were recorded on an Xion 500 Dr. Lange spectrophotometer

\footnotetext{
*martyn.a.sozanskyi@lpnu.ua
} 
in the $340-900 \mathrm{~nm}$ wavelength range. The optical transmission detection accuracy was $\pm 0.5 \%$. The optical band gaps $\left(E_{g}\right)$ were determined from $(\alpha \cdot h v)^{2}$ vs. $h v$ dependences by extrapolating the linear parts of $(\alpha \cdot h v)^{2}$ curves to the intersection with the $h v$ (energy axis) [13].

Investigation of the surface morphology of the films was performed using REMMA-102-02 scanning electron microscope (SEM) with a microanalysis system.

The $\mathrm{pH}$ value of the working solutions was measured with a pH-150 MI pH-meter with a glass combined electrode.

\section{RESULTS AND DISCUSSION}

\subsection{Boundary Conditions Calculation}

In the hydrochemical synthesis of $\mathrm{HgS}_{1-x} \mathrm{Se}_{x}$ films, the formation of mercury complexes with thiourea and citrate, as well as mercury oxide $(\mathrm{HgO})$ as a by-product, is possible. In such a system, the minimum concentration of mercury (II) salt required for the formation of solid $\mathrm{HgS}, \mathrm{HgSe}$ and $\mathrm{HgO}$ phases was calculated using the following equations, respectively [14-16]:

$$
\begin{gathered}
C_{\mathrm{Hg}^{2+}}^{\min }=p S P_{\mathrm{HgS}}-p \alpha_{\mathrm{Hg}^{2+}}-\left(p K_{\mathrm{H}_{2} \mathrm{~S}}^{1,2}-2 p H+\frac{1}{2} p K_{\left(\mathrm{NH}_{2}\right)_{2} \mathrm{CS}}+p\left[\left(\mathrm{NH}_{2}\right)_{2} \mathrm{CS}\right]-p \frac{\beta_{\mathrm{H}_{2} \mathrm{CN}_{2}}}{\beta_{\mathrm{H}_{2} \mathrm{~S}}}\right), \\
C_{\mathrm{Hg}^{2+}}^{\min }=p S P_{\mathrm{HgSe}}-p \alpha_{\mathrm{Hg}^{2+}}-\frac{1}{2}\left(2 p K_{\mathrm{H}_{2} \mathrm{Se}}^{1,2}-2 p H+p K_{\mathrm{SeSO}_{3}^{2-}}+p\left[\mathrm{SeSO}_{3}^{2-}\right]-p \beta_{\mathrm{H}_{2} \mathrm{Se}}\right), \\
p C_{\mathrm{Hg}^{2+}}^{\min }=p S P_{\mathrm{Hg}(\mathrm{OH})_{2}}+2 p H-p \alpha_{\mathrm{Hg}^{2+}}-p K_{\mathrm{H}_{2} \mathrm{O}},
\end{gathered}
$$

where $\beta_{H_{2} S}=\left[H^{+}\right]^{2}+K_{H S^{-}}^{1}\left[H^{+}\right]+K_{H_{2} S}^{1,2}$,

$$
\begin{aligned}
& \beta_{\mathrm{H}_{2} \mathrm{Se}}=\left[\mathrm{H}^{+}\right]^{2}+K_{\mathrm{HSe}^{-}}^{1}\left[\mathrm{H}^{+}\right]+K_{\mathrm{H}_{2} \mathrm{Se}}^{1,2}, \\
& \beta_{\mathrm{H}_{2} \mathrm{CN}_{2}}=\left[\mathrm{H}^{+}\right]^{2}+K_{\mathrm{HCN}_{\overline{2}}}^{1}\left[H^{+}\right]+K_{\mathrm{H}_{2} \mathrm{CN}_{2}}^{1,2},
\end{aligned}
$$

$p$ is an indicator (negative decimal logarithm); $C_{H^{2+}}^{\min }$ is the minimum concentration of $\mathrm{Hg}^{2+}$ ions required to the formation of a solid phase; $S P_{\mathrm{HgS}}$ is the solubility product of $\mathrm{HgS} ; K_{\mathrm{H}_{2} \mathrm{~S}}^{1,2}, K_{\mathrm{H}_{2} \mathrm{Se}}^{1,2}, K_{\mathrm{H}_{2} \mathrm{CN}_{2}}^{1,2}, K_{\left(\mathrm{NH}_{2}\right)_{2} \mathrm{CS}}, K_{\mathrm{SeSO}_{3}^{2-}}$, $K_{\mathrm{H}_{2} \mathrm{O}}$ are constants of hydrogen sulfide, hydrogen selenide, hydrogen cyanamide, thiourea, selenosulfate and water dissociation, respectively; $\alpha_{\mathrm{Hg}^{2+}}$ is the molar fraction of free $\mathrm{Hg}^{2+}$ ions in the solution. The value of $\alpha_{\mathrm{Hg}^{2+}}$ can be found from the following equation:

$$
\alpha_{\mathrm{Hg}^{2+}}=\frac{1}{1+\frac{[L]}{K_{L}^{1}}+\frac{[L]^{2}}{K_{L}^{1,2}}+\ldots+\frac{[L]^{n}}{K_{L}^{1,2, \ldots n}}},
$$

where $[L]$ is the concentration of free ligand $(L)$ of the complexing agent, and $K_{L}^{1,2 \ldots n}$ are the instability constants of $\mathrm{Hg}^{2+}$ complexes with thiourea and citrate.

On the basis of equations (1), (2) and (3), the dependences of the minimum concentration of mercury (II) salt required for the formation of $\mathrm{HgS}, \mathrm{HgSe}$ and $\mathrm{HgO}$ at different $\mathrm{pH}$ values of the working solution were plotted (Fig. 1). The calculations were carried out using the following initial concentrations of compounds: $\left[\left(\mathrm{NH}_{2}\right)_{2} \mathrm{CS}\right]=0.02 \mathrm{M} ;\left[\mathrm{Na}_{3} \mathrm{C}_{6} \mathrm{H}_{5} \mathrm{O}_{7}\right]=0.0015 \mathrm{M}$; $\left[\mathrm{Na}_{2} \mathrm{SeSO}_{3}\right]=0.0001 \mathrm{M}$. The other values of thermodynamic constants used in calculations were taken from [15-17]. Since the stability constant index of the $\mathrm{Hg}^{2+}$

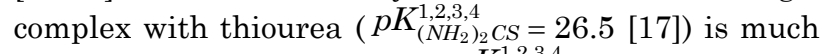
larger than that with citrate $\left(p K_{C_{6} \mathrm{H}_{5} \mathrm{O}_{7}^{3-}}^{1,2,3}=10.9\right.$ [18]), the latter does not significantly affect the calculation of the boundary conditions. The region of possible formation of $\mathrm{HgS}_{1-x} \mathrm{Se}_{x}$ solid solution will be the overlap region of $\mathrm{HgS}$ and HgSe. It coincides with the boundary conditions of HgS, since they are completely located in the region of $\mathrm{HgSe}$ boundary conditions. $\mathrm{HgO}$ as a byproduct can be formed in the $\mathrm{pH}$ region of 11.3-14.0 at concentrations of mercury (II) salt of 0.001-1 M. So, if synthesis is carried out in this $\mathrm{pH}$ region, the $\mathrm{Hg}^{2+}$ concentration should be below these values in order to avoid the formation of $\mathrm{HgO}$.
In practice, it was impossible to obtain coatings at the minimum calculated concentration $\left(10^{-25} \mathrm{M}\right.$ at $\mathrm{pH}=13)$. Therefore, it is necessary to choose such a concentration and $\mathrm{pH}$, at which the rate of formation of the final product will be relatively low with good quality of formed films.

It was experimentally established in Ref. [11] that the optimal value of the mercury salt concentration was $10^{-2} \mathrm{M}$ at $\mathrm{pH}=7.01$. Lower concentrations lead only to slight turbidity, while higher concentrations to high turbidity without film formation or poor film quality, which was unsuitable. The optimal $\mathrm{pH}$ value is in the neutral region of the working solution system, which is used in this work. Similar to the mercury salt concentration effect, reducing the $\mathrm{pH}$ to the acidic region leads only to slight turbidity in the working solution without film formation. Increasing the $\mathrm{pH}$ to the alkaline region leads to high turbidity and formation of mercury chalcogenides or mercury oxide, which also makes it impossible to obtain films in such conditions.

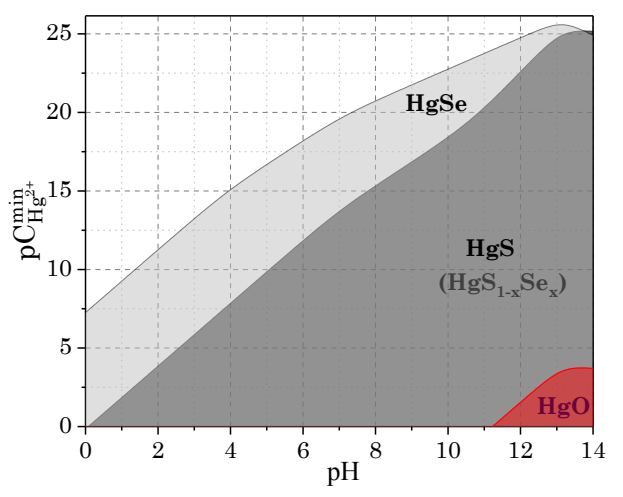

Fig. 1 - Boundary conditions of the HgS, HgSe and HgO solid phase formation in the mercury-thiourea-citrate system

\subsection{Structural and Morphological Properties}

The phase composition of the synthesized samples was determined by X-ray diffraction analysis (Fig. 2). We found that the films consist of $\mathrm{HgS}_{1-x} \mathrm{Se}_{x}$ substitutional solid solutions. According to the obtained XRD data, the structure of the solid solutions changes from trigonal cinnabar modification (structural type $\mathrm{HgS}$ ) to cubic sphalerite modification (structural type $\mathrm{ZnS}$ ). 
This takes place with an increase in $\mathrm{Na}_{2} \mathrm{SeSO}_{3}$ concentration in the working solution and, as a result, an increase in the selenium content in the synthesized films. Similar structural changes of $\mathrm{HgS}_{1-x} \mathrm{Se}_{x}$ solid solution alloys are described in Ref. [19].

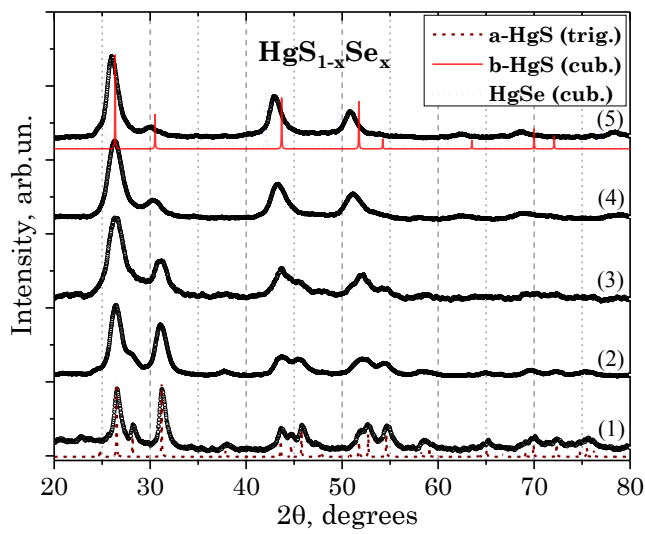

Fig. 2 - Experimental XRD patterns of $\mathrm{HgS}_{1-x} \mathrm{Se}_{x}$ films obtained with different $\mathrm{Na}_{2} \mathrm{SeSO}_{3}$ concentration: $1-1 \cdot 10^{-5} \mathrm{M}$, $2-2.5 \cdot 10^{-5} \mathrm{M}, 3-5 \cdot 10^{-5} \mathrm{M}, 4-7.5 \cdot 10^{-5} \mathrm{M}, 5-1 \cdot 10^{-4} \mathrm{M}$

The results of the surface morphology investigation of $\mathrm{HgS}_{1-x} \mathrm{Se}_{x}$ film samples are shown in Fig. 3. A series of microphotographs shows that $\mathrm{HgS}_{1-x} \mathrm{Se}_{x}$ films deposited at various $\mathrm{Na}_{2} \mathrm{SeSO}_{3}$ concentrations are solid, smooth and uniform over the whole area and reveal a small amount of precipitation and defects on their surface.

A microanalysis of $\mathrm{HgS}_{1-x} \mathrm{Se}_{x}$ films was performed (see Fig. 4). It shows that $\mathrm{HgS}_{1-x} \mathrm{Se}_{x}$ films obtained at minimum $\mathrm{Na}_{2} \mathrm{SeSO}_{3}$ concentration $\left(1 \cdot 10^{-5} \mathrm{M}\right)$ consist of 0.7 at. \% selenium, which corresponds to $x=0.014$ of substitution degree parameter of $\mathrm{HgS}_{1-x} \mathrm{Se}_{x}$ solid solution. The $\mathrm{Na}_{2} \mathrm{SeSO}_{3}$ concentration of $2.5 \cdot 10^{-5}, 5 \cdot 10^{-5}$, $7.5 \cdot 10^{-5}$ and $1 \cdot 10^{-4} \mathrm{M}$ in the working solution leads to 3.4, 8.2, 11.3 and 17.2 at. \% selenium content, respectively (corresponds to $x=0.068,0.164,0.226$ and 0.334 , respectively). Higher concentrations of sodium selenosulfate significantly increase the $\mathrm{pH}$ of the working solution (Table 1) from neutral $(\mathrm{pH}=7.02)$ to slightly alkaline $(\mathrm{pH}=7.20)$ as mentioned above. This leads to a huge increase in the rate of formation of the final product and, accordingly, to difficulties in obtaining it in film form.

\subsection{Optical Properties}

The optical transmission spectra $T(\lambda)$ of $\mathrm{HgS}_{1-x} \mathrm{Se}_{x}$ films obtained at different $\mathrm{Na}_{2} \mathrm{SeSO}_{3}$ concentrations in the working solution are shown in Fig. 5. The minimum and maximum light transmission is observed at the beginning and at the end of the investigated wavelength range, respectively. An increase in the light transmission can be seen with jumps or bends located in the wavelength range of $350-450 \mathrm{~nm}$, which is typical for semiconductor films. With an increase in the $\mathrm{Na}_{2} \mathrm{SeSO}_{3}$ concentration, they are slightly shifted to the longer wavelength region as a result of increasing the selenium amount in deposited $\mathrm{HgS}_{1-x} \mathrm{Se}_{x}$ films.

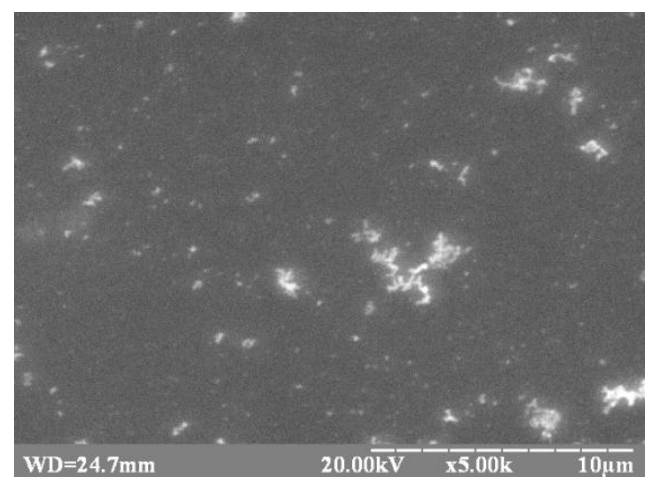

a

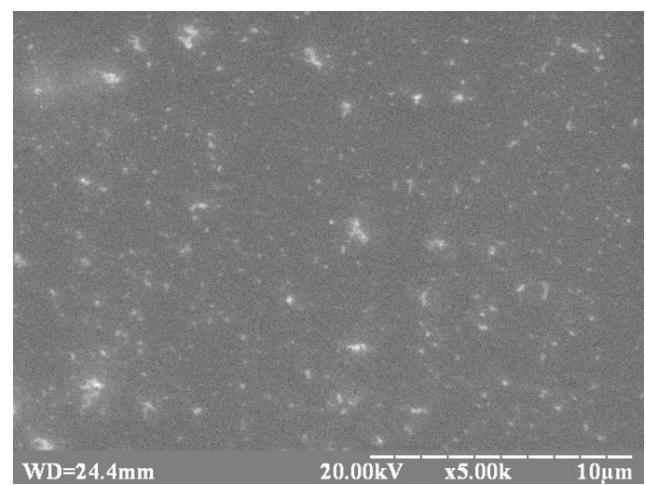

$\mathrm{b}$

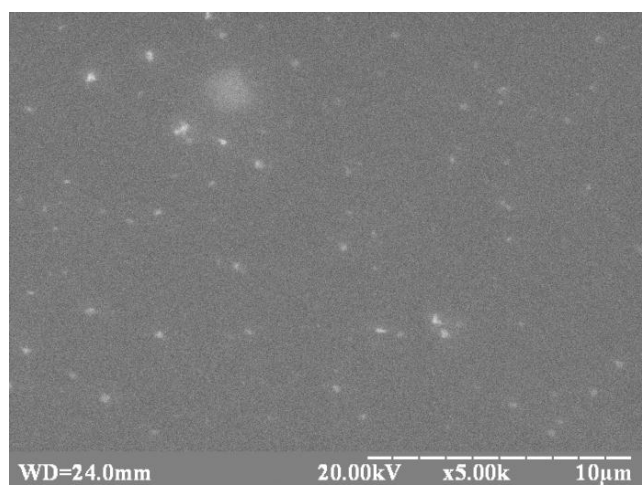

c

Fig. 3 - Surface morphology of $\mathrm{HgS}_{1-x} \mathrm{Se}_{x}$ films obtained with different $\mathrm{Na}_{2} \mathrm{SeSO}_{3}$ concentration: $\mathrm{a}-1 \cdot 10^{-5} \mathrm{M}, \mathrm{b}-5 \cdot 10^{-5} \mathrm{M}$, $\mathrm{c}-1 \cdot 10^{-4} \mathrm{M}$

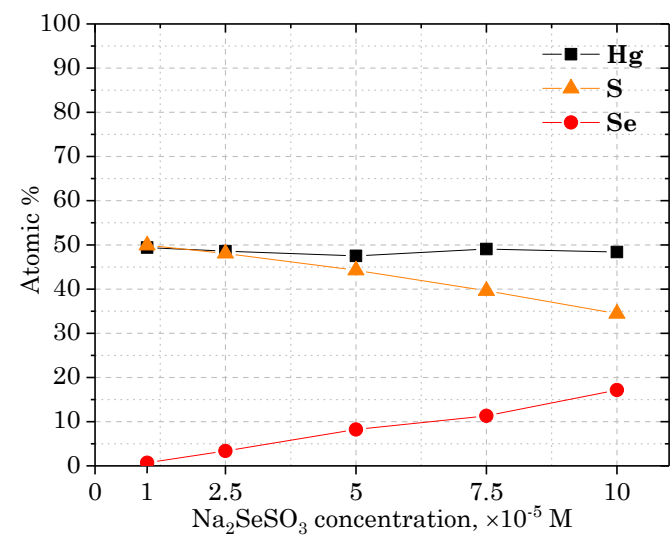

Fig. 4 - Atomic composition of $\mathrm{HgS}_{1-x} \mathrm{Se}_{x}$ films obtained with different $\mathrm{Na}_{2} \mathrm{SeSO}_{3}$ concentration 
Table 1 - Measured $\mathrm{pH}$ values of working solutions

\begin{tabular}{|c|c|}
\hline $\begin{array}{c}\mathrm{Na}_{2} \mathrm{SeSO}_{3} \text { concentration } \\
\text { in the working solution, } \\
\times 10^{-5} \mathrm{M}\end{array}$ & $\begin{array}{c}\mathrm{pH} \\
\text { of the working } \\
\text { solution }\end{array}$ \\
\hline 1.0 & 7.02 \\
\hline 2.5 & 7.06 \\
\hline 5.0 & 7.11 \\
\hline 7.5 & 7.15 \\
\hline 10.0 & 7.20 \\
\hline
\end{tabular}

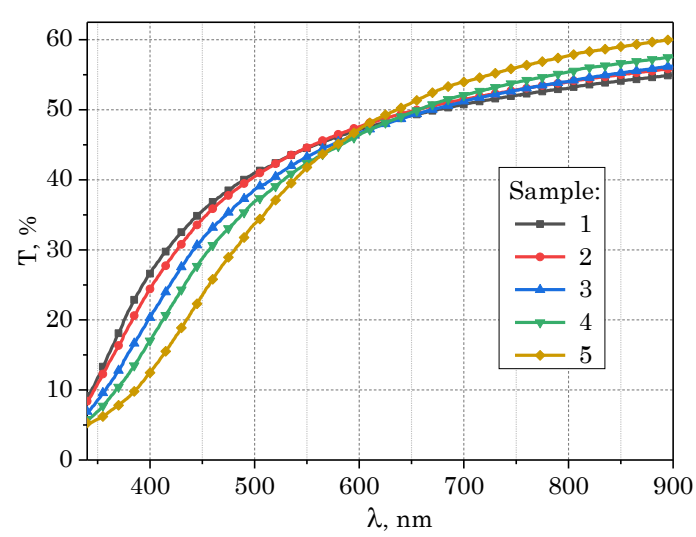

Fig. 6 - Spectral dependences of the optical transmission of $\mathrm{HgS}_{1-x} \mathrm{Se}_{x}$ films obtained with different $\mathrm{Na}_{2} \mathrm{SeSO}_{3}$ concentrations: $\quad 1-1.0 \cdot 10^{-5} \mathrm{M}, \quad 2-2.5 \cdot 10^{-5} \mathrm{M}, \quad 3-5 \cdot 10^{-5} \mathrm{M}$, $4-7.5 \cdot 10^{-5} \mathrm{M}, 5-1.0 \cdot 10^{-4} \mathrm{M}$

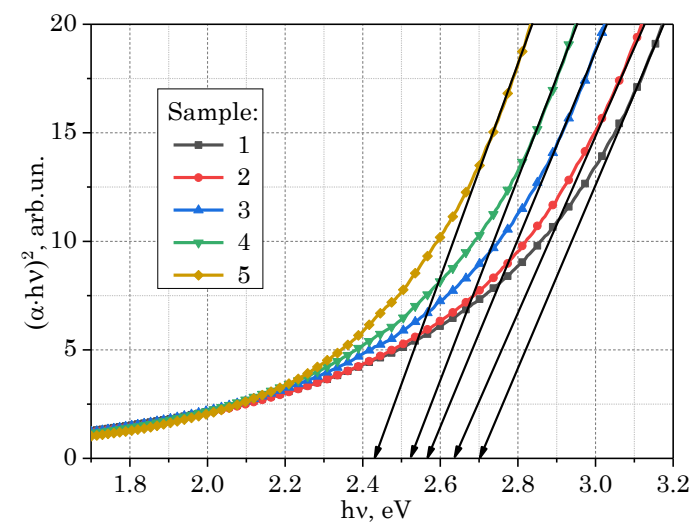

Fig. $7-(a \cdot h v)^{2}=f(h v)$ dependences and determination of the optical band gap values of $\mathrm{HgS}_{1-x} \mathrm{Se}_{x}$ films obtained with different $\mathrm{Na}_{2} \mathrm{SeSO}_{3}$ concentration: $1-1.0^{-10^{-5}} \mathrm{M}, 2-2.5 \cdot 10^{-5} \mathrm{M}$, $3-5 \cdot 10^{-5} \mathrm{M}, 4-7.5 \cdot 10^{-5} \mathrm{M}, 5-1.0 \cdot 10^{-4} \mathrm{M}$

The optical band gap $\left(E_{g}\right)$ of $\mathrm{HgS}_{1-x} \mathrm{Se}_{x}$ films (Fig. 7) decreases numerically from 2.70 to $2.43 \mathrm{eV}$ with an increase in the $\mathrm{Na}_{2} \mathrm{SeSO}_{3}$ concentration in the working

\section{REFERENCES}

1. M. Shepida, O. Kuntyi, G. Zozulya, E. Kaniukov, Appl. Nanosci. 10 No 8, 2563 (2020).

2. W. Choi, G. Park, K. Bae, J. Choi, W. Seo, K. Nam, H. Song, Top. Catal. 61, 965 (2018).

3. M. Shepida, O. Kuntyi, S. Nichkalo, G. Zozulya, S. Korniy, Adv. Mater. Sci. Eng. 2019, 2629464 (2019).

4. M. Altosaar, K. Ernits, J. Krustok, T. Varema, J. Raudoja, E. Mellikov, Thin Solid Films 480-481, 147 (2005).

5. G.V. Colibaba, E.P. Goncearenco D.D. Nedeoglo, N.D. Nedeoglo, Infrared Phys. Techn. 62, 132 (2014). solution. The obtained $E_{g}$ values are between the values for pure $\mathrm{HgS}$ films $(2.84 \mathrm{eV})$ and $\mathrm{HgSe}$ films $(1.42 \mathrm{eV})$, which were found in $[11,20]$. The change in $E_{g}$ can be explained by a smooth change in the semiconductor properties with a change in the substitution parameter $x$ of $\mathrm{HgS}_{1-x} \mathrm{Se}_{x}$ films.

\section{CONCLUSIONS}

The boundary conditions for the formation of mercury sulfide, mercury selenide and mercury oxide phases were found in the mercury-thiourea-citrate system. It was established that the minimum concentration of salt required for the formation of $\mathrm{HgS}$ and $\mathrm{HgSe}$ is in the alkaline region. The region of possible formation of $\mathrm{HgS}_{1-x} \mathrm{Se}_{x}$ solid solution is the overlap region of $\mathrm{HgS}$ and $\mathrm{HgSe}$. But in practice, the formation of films occurs in the neutral $\mathrm{pH}$ region, since alkaline medium causes higher formation rate of mercury chalcogenides and, accordingly, difficulties in obtaining them in film form.

Films of $\mathrm{HgSS}_{1-x} \mathrm{Se}_{x}$ solid solution were obtained on glass substrates by hydrochemical synthesis method with different $\mathrm{Na}_{2} \mathrm{SeSO}_{3}$ concentration. The $\mathrm{pH}$ value of the working solutions varies in the range from 7.02 to 7.20 , which is favorable for the synthesis of the final product in film form.

The phase and elemental composition, surface morphology and optical properties of $\mathrm{HgS}_{1-x} \mathrm{Se}_{x}$ films were studied. It was found that films consist of substitutional solid solutions, the structure of which changes from trigonal to cubic. The results of optical transmission measurements of solid solution films show the increase in the light transmission with jumps or bends in the wavelength range of $350-450 \mathrm{~nm}$. The optical band gap of the coatings was $2.70-2.43 \mathrm{eV}$. $\mathrm{HgS}_{1-x} \mathrm{Se}_{x}$ films had different elemental composition, starting from 0.7 at. \% $(x=0.014)$ up to 17.2 at. $\%(x=0.334)$ of selenium content. Their surface is solid, smooth and uniform over the whole area and reveals a small number of precipitated particles and defects. It was not possible to obtain films at larger values of the substitution parameter $x$, since $\mathrm{HgS}_{1-x} \mathrm{Se}_{x}$ forms much faster at a concentration of sodium selenosulfate higher than $1.0 \cdot 10^{-4} \mathrm{M}$ in the mercury-thiourea-citrate system.

Based on the obtained results of hydrochemical synthesis and studies in this work, the prepared film samples of $\mathrm{HgS}_{1-x} \mathrm{Se}_{x}$ solid solution, due to its variable semiconductor properties, can be used for the manufacture of semiconductor materials for various electronic device applications.

6. S.K. Shinde, D.P. Dubal, G.S. Ghodakec, V.J. Fulari, RSC Adv. 4, 33184 (2014).

7. M.A. Sozanskyi, P.Yo. Shapoval, R.R. Guminilovych, V.E. Stadnik, Yo.Yo. Yatchyshyn, Funct. Mater. 27 No 2, 396 (2020)

8. R. Mariappan, V. Ponnuswamy, M. Ragavendar, Optik. 123, 1196 (2012)

9. R.S. Mane, C.D. Lokhande, Mater. Chem. Phys. 65, 1 (2000).

10. S.M. Pawar, B.S. Pawar, J.H. Kim, O.S. Joo, C.D. Lokhande, Curr. Appl. Phys. 11, 117 (2011). 
11. M. Sozanskyi, V. Stadnik, R. Guminilovych, P. Shapoval, M. Laruk, Yo. Yatchyshyn, Visnyk of the Lviv University. Series Chemistry, 60 No 1, 146 (2019).

12. W. Kraus, G Nolze, J. Appl. Crystall. 29 No 3, 301 (1996).

13. Yu. Yeromenko, A. Opanasyuk, A. Voznyi, I. Shpetnyi, Yu. Gnatenko, V. Grebinaha, Funct. Mater. 26 No 1, 16 (2019).

14. M.A. Sozanskyi, P.Yo. Shapoval, R.R. Guminilovych, M.M. Laruk, Yo.Yo. Yatchychyn, Voprosy Khimii $i$ Khimicheskoi Tekhnologii 2019 No 2, 39 (2019).

15. M.A. Sozanskyi, V.E. Stadnik, R.T. Chaykivska, P.Yo. Shapoval, Yo.Yo. Yatchyshyn, L.O. Vasylechko, Voprosy Khimii $i$
Khimicheskoi Tekhnologii 2018 No 4, 69 (2018).

16. S.S. Tulenin, S.A. Bakhteev, R.A. Yusupov, L.N. Maskaeva, V.F. Markov, Russ. J. Phys. Chem. A. 87, 1771 (2013).

17. G. Zuo, M. Muhammed, Solvent Extr. Ion. Exc. 13, 855 (1995).

18. Yu.Yu. Lur'e, Handbook on analytical chemistry (Moscow: Khimiya: 1989 [in Russian].

19. V. Tomashyk, P. Feychuk, L Shcherbak, Ternary Alloys Based on II-VI Semiconductor Compounds (CRC Press: Taylor \& Francis Group: 2014).

20. P. Pramanik, S. Bhattacharya, Mater. Res. Bull. 24, 945 (1989).

\title{
Гідрохімічний синтез плівкових твердих розчинів $\mathrm{HgS}_{1-x} \mathrm{Se}_{x}$
}

\author{
М.А. Созанський, П.Й. Шаповал, В.Є. Стаднік, О.П. Курило, М.М. Ларук
}

Національний університет «Львівська політехніка», вул. Степана Бандери, 12, 79013 Львів, Україна

Плівки твердого розчину сульфіду-селеніду ртуті $\left(\mathrm{HgS}_{1-x} \mathrm{Se}_{x}\right)$ синтезовано на скляних підкладках методом гідрохімічного осадження. Використано водні розчини нітрату ртуті (II), тіосечовини, натрій селеносульфату та тринатрій цитрату. Проведено теоретичний розрахунок граничних умов утворення сульфіду ртуті, селеніду ртуті та оксиду ртуті в системі ртуть-тіосечовина-цитрат. Згідно з виконаним рентгенофазовим та елементним аналізом, отримані зразки плівок е однофазними і складаються із твердих розчинів заміщення $\mathrm{HgS}_{1-x} \mathrm{Se}_{x}$. Досліджено вплив концентрації селеносульфату натрію на ступінь заміщення S-Se покриттів $\mathrm{HgS}_{1-x} \mathrm{Se}_{x}$. Встановлено, що параметр $x$ змінюеться від 0.068 до 0.334 із збільшенням вмісту $\mathrm{Na}_{2} \mathrm{SeSO}_{3}$ від $1 \cdot 10^{-5}$ до $1 \cdot 10^{-4} \mathrm{M}$. В той же час, модифікація структури $\mathrm{HgS}_{1-x} \mathrm{Se}_{x}$ змінюеться з кіновару до сфалериту. Більш високі концентрації селеносульфату натрію дають занадто високу швидкість формування кінцевого продукту, i, відповідно, складність отримання покриттів. Досліджено морфологічні та оптичні властивості плівок $\mathrm{HgS}_{1-x} \mathrm{Se}_{x}$. Їхня поверхня е суцільною, однорідною і мае невелику кількість поверхневих дефектів. Оптичне пропускання плівок $\mathrm{HgS}_{1-x} \mathrm{Se}_{x}$ збільшується в досліджуваній області довжин хвиль від 340 до 900 нм. Крива пропускання має стрибок в області 400 нм, який зміщуеться вправо зі збільшенням вмісту селену в $\mathrm{HgS}_{1-x} \mathrm{Se}_{x}$, відповідно, оптична ширина забороненої зони плівок зменшуеться з 2.70 до 2.43 еВ.

Ключові слова: Сульрід ртуті, Селенід ртуті, Плівки, Тверді розчини, Хімічне осадження, Оптичні властивості. 